\title{
Xeroderma Pigmentosum
}

\author{
Jennifer O. Black ${ }^{1}$
}

Received: 20 November 2015/Accepted: 8 February 2016/Published online: 14 March 2016

(C) Springer Science+Business Media New York 2016

\begin{abstract}
Xeroderma pigmentosum (XP) is a rare disorder of defective UV-radiation induced damage repair that is characterized by photosensitivity with easy skin burning following minimal sun exposure, early freckling and development of lentiginous pigmentation along with other features of poikiloderma and a propensity for developing skin cancer at an early age. In this short review, the clinical, pathological, genetic and molecular aspects of XP are reviewed in the current literature. XP encompasses a spectrum of disease that overlaps with other diseases of DNA repair systems. In addition to cutaneous complications, patients are susceptible to eye conditions, neurodegenerative processes, central nervous system tumors and other tumors as a result of UV radiation exposure and its byproducts. Patients with XP frequently experience a shorter life span due to skin cancer and neurodegenerative sequelae, but aggressive preventative measures to minimize UV radiation exposure and damage can improve the course of disease and prolong life. The disease has served as a model for photoaging and UV radiation-induced cancer and has led to a better understanding of cell processes that prevent development of these disease features in normal individuals.
\end{abstract}

Keywords Xeroderma pigmentosum - UV radiation . Nucleotide excision repair pathway

Jennifer O. Black

jennifer.black2@childrenscolorado.org

1 Division of Pediatric Pathology, Department of Pathology and Laboratory Medicine, Children's Hospital Colorado, University of Colorado Anschutz Medical Campus, 13123 East 16th Avenue, Box 120, Aurora, CO 80045, USA

\section{Introduction}

Xeroderma pigmentosum (XP) is a rare autosomal recessive disorder that has been reported around the world with variable prevalence, affecting 1 per million in the United States, 2.3 per million in Western Europe, and 45 per million in Japan [1]. Affected populations have also been described in North Africa and the Middle East, with less well-understood frequency [1-4].

XP was first described in 1874 by dermatologist Moriz Kaposi based on a series of four patients with thin, dry skin showing wrinkling, checkered pigmentation, small dilatations of the vessels, skin contraction, and development of skin-based tumors [5]. The spectrum of disease was expanded by subsequent reports to include neurologic abnormalities [6] as well as a severe form characterized by dwarfism, gonadal hypoplasia, and mental deficiency along with the conventional features of XP [7]. As early as 1926, the disease pathophysiology was recognized as congenital extreme sensitization of the skin to ultra-violet (UV) rays of the sun, with clear value in preventive measures to minimize sun exposure [8].

Early investigations supported the importance of UV radiation in the disease pathogenesis of XP [9]. Cleaver et al. [10] described defective DNA repair in cultured skin fibroblasts and subsequent investigators showed that XP cells are not able to clear UV photoproducts or employ excision repair to mend UV radiation damage to DNA [1114]. XP-variant was characterized by Burk et al. [15] and Cleaver et al. [16] as being a form of XP with intact DNA excision repair capability. Further studies showed heterogeneity in the molecular abnormalities comprising XP [17], revealing different forms of XP with a variety of defects that when combined, could collectively overcome UVdamaged DNA repair defects. This complementary 
capacity inspired the description of complementation groups, distinct subtypes of XP with different DNA excision repair defects [18]. These subtypes are summarized in Table 1, and include XP types A-G and XP variant (XPV). Further investigations over the years have revealed the exact molecular abnormalities responsible for the complement types [18].

\section{Discussion}

The repair process of UV-radiation induced DNA damage has been summarized in a recent review by DiGiovanna et al. [18]. When DNA is exposed to UV radiation, multiple nucleic acid based photoproducts result that serve as the substrate for DNA repair via the nucleotide excision repair (NER) process. The damaged DNA is recognized within actively transcribed genes through the transcription-coupled repair (TCR) pathway and in the remainder of the genome via the slower global genome repair (GGR) pathway. In the TCR pathway, specialized proteins (CSA and CSB gene products) recognize the abnormal segment and block RNA polymerase II activity. In the GGR pathway, a different set of proteins (DDB2, the XPE gene product, and XPC gene products) recognize abnormal UValtered DNA, effectively marking them for repair. Both pathways then lead to unwinding of the DNA helix in the region of damaged DNA via multiple different proteins including two helicases, ERCC3 and ERCC2, encoded by the $X P B$ and $X P D$ genes, respectively, and additional proteins including the XPA and XPG (ERCC5) gene products and replication protein A (RPA). Endonucleases XPF (ERCC4) and XPG (ERCC5) incise the DNA strand and excise small fragments of the affected genome. The resulting defect is repaired using well-understood DNA synthesis pathways involving DNA polymerase and ligases.

Mutations in any of these proteins from either the TCR, GGR, or common NER pathways lead to abnormalities in DNA repair. These mutations have resulted in multiple

Table 1 Mutations in the NER pathway and corresponding clinical sequela

\begin{tabular}{|c|c|c|c|}
\hline Gene & Normal protein function & Clinical syndrome & Disease characteristics \\
\hline$X P A$ & Protein that assists with DNA unwinding & XP-A & $\begin{array}{l}\text { Photosensitivity, poikiloderma, lentigines, skin } \\
\text { cancer, neurodegeneration }\end{array}$ \\
\hline $\begin{array}{l}X P B / \\
\quad E R C C 3\end{array}$ & Helicase involved with DNA unwinding & XP-B, CS, TTD & $\begin{array}{l}\text { Photosensitivity, poikiloderma, lentigines, skin } \\
\text { cancer, neurodegeneration }\end{array}$ \\
\hline$X P C$ & Protein recognizing global genome defects & $\mathrm{XP}-\mathrm{C}$ & $\begin{array}{l}\text { Photosensitivity, poikiloderma, lentigines, skin } \\
\text { cancer }\end{array}$ \\
\hline $\begin{array}{l}X P D / \\
E R C C 2\end{array}$ & Helicase involved with DNA unwinding & XP-D, TTD, COFS, CS & $\begin{array}{l}\text { Photosensitivity, poikiloderma, lentigines, skin } \\
\text { cancer, neurodegeneration, brain tumors }\end{array}$ \\
\hline $\begin{array}{l}X P E / \\
D D B 2\end{array}$ & Protein recognizing global genome defects & XP-E & $\begin{array}{l}\text { Photosensitivity, poikiloderma, lentigines, skin } \\
\text { cancer, neurodegeneration }\end{array}$ \\
\hline $\begin{array}{l}X P F / \\
\quad E R C C 4\end{array}$ & $\begin{array}{l}\text { Forms an endonuclease together with ERCC1 } \\
\text { that incises damaged DNA for repair }\end{array}$ & $\begin{array}{l}\text { XP-F, XFE progeroid } \\
\text { syndrome, Fanconi } \\
\text { anemia }\end{array}$ & $\begin{array}{l}\text { Photosensitivity, poikiloderma, lentigines, skin } \\
\text { cancer, neurodegeneration, brain tumors }\end{array}$ \\
\hline $\begin{array}{l}X P G / \\
E R C C 5\end{array}$ & Endonuclease that incise damaged DNA & XP-G & $\begin{array}{l}\text { Photosensitivity, poikiloderma, lentigines, skin } \\
\text { cancer, neurodegeneration }\end{array}$ \\
\hline $\begin{array}{l}X P V / \\
P O L H\end{array}$ & $\begin{array}{l}\text { DNA-polymerase eta (pol-eta) which performs } \\
\text { trans-lesion DNA synthesis past ultraviolet } \\
\text { (UV) }\end{array}$ & XP Variant & Milder photosensitivity and poikiloderma \\
\hline ERCC1 & $\begin{array}{l}\text { Forms an endonuclease together with } X P F / \\
E R C C 4 \text { that incises damaged DNA for repair }\end{array}$ & $\mathrm{XP}, \mathrm{CS}, \mathrm{COFS}$ & $\begin{array}{l}\text { Photosensitivity, poikiloderma, lentigines, skin } \\
\text { cancer, neurodegeneration }\end{array}$ \\
\hline $\begin{array}{l}\text { CSA/ } \\
\text { ERCC8 }\end{array}$ & $\begin{array}{l}\text { DNA excision repair protein involved in the TCR } \\
\text { pathways }\end{array}$ & $\mathrm{CS}$ & $\begin{array}{l}\text { Growth failure, impaired neurodevelopment, } \\
\text { photosensitivity, eye disorders, premature aging }\end{array}$ \\
\hline $\begin{array}{l}\text { CSB/ } \\
\text { ERCC6 }\end{array}$ & $\begin{array}{l}\text { DNA excision repair protein involved in the TCR } \\
\text { pathway }\end{array}$ & $\mathrm{CS}, \mathrm{COFS}$ & $\begin{array}{l}\text { Growth failure, severely impaired } \\
\text { neurodevelopment, photosensitivity, eye } \\
\text { disorders, premature aging }\end{array}$ \\
\hline GTF2H5 & $\begin{array}{l}\text { TTDA protein stabilizes the DNA/protein } \\
\text { complex during unwinding of DNA strand for } \\
\text { repair }\end{array}$ & TTD & $\begin{array}{l}\text { Brittle hair, intellectual impairment, } \\
\text { photosensitivity }\end{array}$ \\
\hline $\begin{array}{l}\text { TTDN1/ } \\
\text { C7orf11 }\end{array}$ & Regulates mitosis and cytokinesis & TTD & Non-photosensitive TTD \\
\hline
\end{tabular}


clinical syndromes, some with overlapping features, including XP, Cockayne syndrome (CS), cerebro-oculofacial-skeletal syndrome (COFS), and trichothiodystrophy (TTD), summarized in Table 1.

The classic phenotype of XP manifests in early childhood as freckling before the age of 2 years, severe burning following minimal sun exposure and skin cancer presenting at an early age [1-3, 18-20]. The median age for the first appearance of skin cancer has been reported as 9 years (age range of 1-32 years) for non-melanocytic skin cancer and 22 years for melanoma (age range $2-47$ years) [19]. The skin of affected individuals also undergoes premature aging, with progressive atrophy, dryness, telangiectasias, and abnormal lentiginous pigmentation with intermixed hypopigmented and hyperpigmented areas (Figs. 1, 2).

Squamous cell carcinoma, basal cell carcinoma, and melanoma all occur in patients with XP. XP patients have a $>10,000$ fold risk over their lives of developing nonmelanocytic skin cancer compared to the general population and $>2000$ fold risk for melanoma [19]. This increased risk of cancer results in a 58 year reduction in age at the first non-melanocytic skin cancer to arise in XP patients and a 33 year reduction in age at the first melanoma [19]. This pattern is the reverse from that observed in patients without XP, who are more likely to develop melanoma at an earlier age than non-melanocytic skin tumors, and also suggests that mechanisms for malignant transformation are different between melanocytic and non-melanocytic skin cancer $[18,21]$. Furthermore, there appear to be distinct

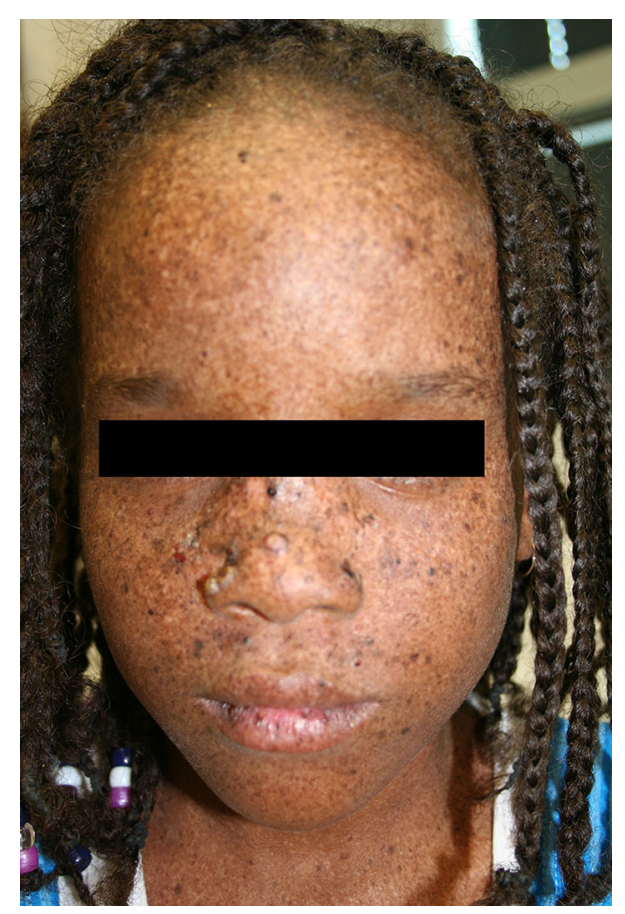

Fig. 1 A young girl with xeroderma pigmentosum

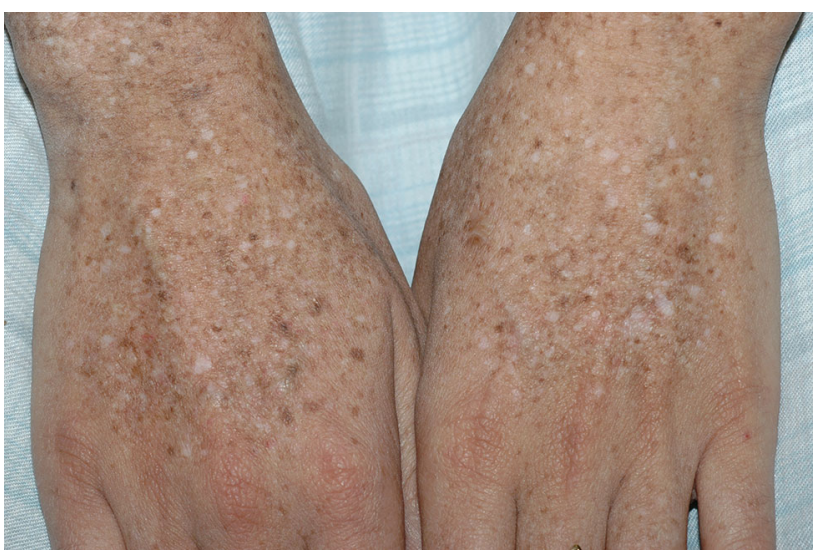

Fig. 2 The hands of a 21-year-old woman with xeroderma pigmentosum

differences in the melanocytic lesions seen in XP patients compared to the general population. DNA sequencing studies have shown that PTEN mutations are far more frequent $(53 \%)$ in XP melanomas than in the general population $(16 \%)$, and the PTEN mutations are characteristic of UV radiation-induced changes [21]. Also, the nevi of XP patients have a slightly different histology from typical nevi and they also show more frequent PTEN mutations [21]. Not all patients develop skin cancer, and in a retrospective study from Bradford et al. [19] $33 \%$ reported no skin cancer. A subset of XP patients report not experiencing sun burn (about $38 \%$ in the Bradford study), but these patients were more likely to be diagnosed with skin cancer at an earlier age than those who report skin burning, likely due to increased use of preventative measures against skin burning that would lead to decreased UV radiation exposure [19].

All complement types of XP have photosensitivity and increased skin cancer risk, but there are a few differences between the types. XPC, XPE and XPV types have been associated with less severe sun burning after minimal sun exposure and they may tan, but still acquire abnormal pigmentation $[19,22]$. Neurodegeneration is not seen uniformly in all types, but is most commonly associated with XPA, XPB, XPD, XPF and XPG types and rarely with $\mathrm{XPC}$ and XPE types [23]. There is also great variability within complementation groups due to individual UV radiation exposure and preventive measures. XPC is the most common complement type in the United States, Europe, and North Africa while XPA is the most common type in Japan [19, 20]. The XPV type has clinical overlap with the other forms but does not involve a mutation of the NER system. Instead, XPV is caused by a mutation in DNA polymerase $\eta$ (pol $\eta$ ). Pol $\eta$ is an error-prone polymerase that when functioning normally, allows transcription past UV-damaged DNA [24]. XPV patients may have increased long-term survival compared to other XP types [25]. 
Patients with XP experience a variety of ophthalmologic conditions, as the anterior parts of the eye are also at risk for increased UV radiation exposure. In a long-term follow-up study by Brooks et al., $91 \%$ of XP patients reported some type of ocular abnormality [26]. The most common abnormalities in the study included conjunctivitis $(51 \%)$, corneal neovascularization (44\%), dry eye (38\%), corneal scarring $(26 \%)$, ectropion $(25 \%)$, blepharitis (23\%), conjunctival melanosis $(20 \%)$, and cataracts (14\%). Thirteen percent of patients had some degree of visual axis impingement, and $5 \%$ of patients had no light perception in 1 or both eyes. Ocular surface cancer or a history of ocular surface cancer was present in $10 \%$ of patients. Other findings include pterygium, pinguecula, keratitis, loss of lashes, band keratopathy, Bowman's layer break, epithelial bulbi, cataract, ciliary body hamartoma, iritis, macular edema, chorioretinal adhesions, pigmentary retinal degeneration with pigment migration, cystoid degeneration, gliosis, drusen, and optic nerve atrophy [20, 26].

The central nervous system (CNS) is affected in a significant subset of XP patients [18, 20, 23]. The CNS does not have direct UV radiation exposure making the mechanism of disease unclear, but unrepaired oxidative damage has been proposed as a possible cause [23]. Neurodegeneration occurs in an estimated $24 \%$ [19], including loss of intellectual functioning, deterioration of neurologic status, impaired hearing, abnormal speech, areflexia, ataxia, peripheral neuropathy, and loss of the ability to walk and talk. These deficiencies correlate with neuronal loss, cortical atrophy and ventricular dilatation without inflammation as seen with imaging studies and pathologic examination. The most affected complementation groups are patients with XPD and XPA mutations [19]. XP patients also have a 50-fold increased risk of developing brain tumors, including medulloblastoma, glioblastoma, spinal cord astrocytoma, and schwannoma [18, 20]. XP patients with neurodegenerative disease developed skin cancer at an earlier age than those who do not (XPC and variant groups) [19]. Skin cancer accounts for the highest number of disease-related deaths in XP patients, but neurodegeneration is the second leading cause. Among patients with XP, those with neurodegeneration showed an earlier median age at death (29 years) compared with those who had no neurologic degeneration (median age at death 37 years) [19].

XP patients who smoke have an increased risk of lung cancer compared to the general population, among other cancers, as cigarette smoke components have mutagenic effects similar to UV radiation [18]. Skin cancers can also occur in unusual sites that get less UV radiation exposure, including the tongue. African and African-American XP patients had similar rates of cancer to the non-Hispanic whites in one study [19] and have an increased risk of skin cancer on the anterior tongue. The most common cause of death in XP patients is skin cancer, most frequently due to metastatic melanoma or invasive squamous cell carcinoma [19].

The overlap and related syndromes that share features with XP have also revealed information about the varying roles of genes implicated in the NER process. Cockayne syndrome (CS) results from mutations in the CSA or CSB genes, which in addition to having a role in the NER pathway, also appear to have roles in general transcription processes and possibly in mitochondrial maintenance. CS is characterized by short stature with microcephaly, pigmentary retinal degeneration, kyphoscoliosis, gait defects, sensorineural deafness, and distinct facial features including deep-set eyes, prominent ears and a wizened appearance [27]. Multiple types have been described. Type I has a moderate phenotype, with normal prenatal development and developmental abnormalities manifesting in the first 2 years of life followed by progressive impairment and disability culminating in death in the first or second decade of life. Type II is more severe and involves growth failure at birth without subsequent neurodevelopment and death in the first decade of life. Type III has milder symptoms or later onset. These patients have photosensitivity but do not have pigmentation abnormalities and do not have an increased risk of developing cutaneous malignancy. Their neurodegenerative features are secondary to demyelination, and they have increased deep tendon reflexes, unlike individuals with XP. Neuroimaging shows cerebral atrophy, ventricular dilation, calcification of the basal ganglia and cerebral cortex, and neuronal loss [27].

Trichothiodystrophy is characterized by abnormal hair, intellectual impairment, decreased fertility, short stature, and ichthyosis [27]. Photosensitivity is usually present and associated with $X P D, X P B, T T D A$ gene mutations but not TTDN1 mutations. Similar to CS, TTD does not have an increased association with malignancy or abnormal pigmentation. The brittle hair of TTD is sulfur-deficient and shows a striped light and dark pattern with polarizing light microscopy. Also, similar to CS, abnormal neurologic features are believed to be due to abnormal myelin development and transcriptional abnormalities, without the neurologic deterioration seen in XP. Neuroimaging shows dysmyelination but can also show cortical heterotopias, partial agenesis of the corpus callosum, perimedullary fibrosis of the spinal cord, and intracranial calcifications [27].

COFS is an autosomal recessive disease characterized by microcephaly, congenital cataracts and microphthalmia, arthrogryposis, severe developmental delay, severe postnatal growth failure, photosensitivity, and facial dysmorphism with a prominent nasal root and overhanging upper 
lip. Multiple mutations in the NER system have been implicated, mostly involving the TCR pathway, including $C S B, X P D, X P G$, and ERCCl genes [28].

There is currently no cure for xeroderma pigmentosum, but there is profound benefit in consistent UV-radiation protection, which can substantially decrease the number of skin cancers, and consists of layered clothing along with sunscreen and eye protection [21]. Decreasing UV radiation exposure may not decrease neurodegenerative effects. Patients often require Vitamin D supplementation to offset sun avoidance [21]. Systemic treatment with retinoids has been attempted and shows some benefit in reducing the number of skin cancers [29], though side effects prohibit use in children. Early resection of premalignant and malignant lesions is important for long term survival. Investigative therapies using gene therapy and antioxidants to reduce oxidative damage may result in future treatment options [30].

\section{Conclusion}

In summary, XP is a rare disease that has taught the scientific community volumes about UV radiation-induced DNA damage and how the human body adjusts to that damage under normal conditions and when repair systems are defective. Early diagnosis and preventive measures can dramatically improve the lives of affected patients and prolong their lives.

Acknowledgments I would like to thank Bahig M. Shehata, MD, Professor of Pediatric Pathology, Children's Healthcare of Atlanta, Atlanta, Georgia, for contribution of Fig. 1.

\section{References}

1. Kraemer KH, Lee MM, Scotto J. Xeroderma pigmentosum: Cutaneous, ocular, and neurologic abnormalities in 830 published cases. Arch Dermatol. 1987;123:241-50.

2. Lehmann AR, McGibbon D, Stefanini M. Xeroderma pigmentosum. Orphanet J Rare Dis. 2011;6:70-145.

3. Robbins JH, Kraemer KH, Lutzner MA, et al. Xeroderma pigmentosum: An inherited disease with sun sensitivity, multiple cutaneous neoplasms, and abnormal DNA repair. Ann Intern Med. 1974;80:221-48.

4. Kleijer WJ, Laugel V, Berneburg M. Incidence of DNA repair deficiency disorders in western Europe: Xeroderma pigmentosum, Cockayne syndrome and trichothiodystrophy. DNA Repair (Amst). 2008;7:744-50.

5. Hebra F, Kaposi M. On diseases of the skin including exanthemata, volume III. New Sydenham Soc. 1874;61:252-8.

6. Neisser A. Ueber das 'Xeroderma pigmentosum' (Kaposi): Lioderma essentialis cum melanosi et telangiectasia. Vierteljahrschr Dermatol Syphil. 1883;47-62:0000.

7. de Sanctis C. Cacchione: A L'idiozia xerodermica. Riv Sper Freniatr. 1932;56:269-92.
8. Per M. Xeroderma pigmentosum (Kaposi): report of a case, with special reference to clinical features and pathogenesis. $\mathrm{Br} \mathrm{J}$ Dermatol. 1926;38:241-52.

9. Gartler SM. Inborn errors of metabolism at the cell culture level. Presented at the International Medical Congress, New York, NY; 1964.

10. Cleaver JE. Defective repair replication of DNA in xeroderma pigmentosum. Nature. 1968;218:652-6.

11. Setlow RB, Regan JD, German J, et al. Evidence that xeroderma pigmentosum cells do not perform the first step in the repair of ultraviolet damage to their DNA. Proc Natl Acad Sci USA. 1969;64:1035-41.

12. Cleaver JE, Trosko JE. Absence of excision of ultraviolet-induced cyclobutane dimers in xeroderma pigmentosum. Photochem Photobiol. 1970;11:547-50.

13. Reed WB, Landing B, Sugarman G, et al. Xeroderma pigmentosum. Clinical and laboratory investigation of its basic defect. JAMA. 1969;207:2073-9.

14. Epstein JH, Fukuyama K, Reed WB, et al. Defect in DNA synthesis in skin of patients with xeroderma pigmentosum demonstrated in vivo. Science. 1970;168:1477-8.

15. Burk PG, Lutzner MA, Clarke DD, et al. Ultraviolet-stimulated thymidine incorporation in xeroderma pigmentosum lymphocytes. J Lab Clin Med. 1971;77:759-67.

16. Cleaver JE. Xeroderma pigmentosum: variants with normal DNA repair and normal sensitivity to ultraviolet light. J Invest Dermatol. 1972;58:124-8.

17. De Weerd-Kastelein EA, Keijzer W, Bootsma D. Genetic heterogeneity of xeroderma pigmentosum demonstrated by somatic cell hybridization. Nat New Biol. 1972;238:80-3.

18. DiGiovanna JJ, Kraemer KH. Shining a light on xeroderma pigmentosum. J Invest Dermatol. 2012;132:785-96.

19. Bradford PT, Goldstein AM, Tamura D, et al. Cancer and neurologic degeneration in xeroderma pigmentosum: long term follow-up characterises the role of DNA repair. J Med Genet. 2011;48:168-76.

20. Karass M, Naguib MN, Elawabdeh N, et al. Xeroderma pigmentosa: three new cases with an in depth review of the genetic and clinical characteristics of the disease. Fetal and Pediatr Pathol. 2015;34:120-7.

21. Masaki T, Wang Y, DiGiovanna JJ, et al. High frequency of pTEN mutations in nevi and melanomas from xeroderma pigmentosum patients. Pigment Cell Melanoma Res. 2014;7:454-64.

22. Tamura D, DiGiovanna JJ, Khan SG, et al. Living with xeroderma pigmentosum: comprehensive photoreception for highly photosensitive patients. Photodermatol Photoimmunol Photomed. 2014;30:146-52.

23. Anttinen A, Koulu L, Nikoskelainen E, et al. Neurological symptoms and natural course of xeroderma pigmentosum. Brain. 2008;131:1979-89.

24. Masutani C, Kusumoto R, Yamada A, et al. The XPV (xeroderma pigmentosum variant) gene encodes human DNA polymerase eta. Nature. 1999;399:700-4.

25. Broughton BC, Cordonnier A, Kleijer WJ, et al. Molecular analysis of mutations in DNA polymerase eta in xeroderma pigmentosum-variant patients. Proc Natl Acad Sci USA. 2002;99:815-20.

26. Brooks BP, Thompson AH, Bishop RJ, et al. Ocular manifestations of xeroderma pigmentosum: long-term follow-up highlights the role of DNA repair in protection from sun damage. Ophthalmology. 2013;120:1324-36.

27. Shabbir SH. DNA repair dysfunction and neurodegeneration: lessions from rare pediatric disorders. J Child Neurol. 2016;31:392-6.

28. Suzumura H, Arisaka O. Cerebro-oculo-facio-skeletal syndrome. Adv Exp Med Biol. 2010;685:210-4. 
29. Kraemer KH, DiGiovann JJ. Forty years of research on xeroderma pigmentosum at the US National Institutes of Health. Photochem Photobiol. 2015;91:452-9.
30. Dupuy A, Sarasin A. DNA damage and gene therapy of xeroderma pigmentosum, a human DNA repair-deficient disease. Mutat Res. 2015;776:2-8. 